\title{
Personal income tax and income inequality in Ecuador between 2007 and 2011
}

\author{
Liliana Cano
}

\begin{abstract}
This paper uses data from individual income tax returns to explore the redistributive effect of personal income tax in Ecuador between 2007 and 2011. Following common practice in tax incidence analysis, we first compute indices of income tax progressivity and redistributive impact. We then mobilize microsimulation techniques to simulate the redistributive effect of personal income tax under different taxable income scenarios. Finally, we calculate the effective tax rates paid by top income groups and derive a range of optimal income taxes for the top 1\% income group. We obtain two main empirical results. First, although Ecuador's personal income tax is highly progressive, its redistributive capacity is low: our findings show that high-income individuals are more likely to reduce their taxable income through legal tax deductions than low-income individuals. Second, while the effective tax rates paid by high-income individuals are relatively low, optimal tax rates could be as high as 63\%.
\end{abstract}

\section{Keywords}

Income tax, fiscal policy, income distribution, mathematical models, simulation methods, Ecuador

\section{JEL classification}

D31, H24, O54

\section{Author}

Liliana Cano is a postdoctoral researcher with the Research Laboratory on Economics, Policy and Social Systems (LEREPS) of the University of Toulouse 1 Capitole, France. Email: liliana.cano@ut-capitole.fr. 


\section{Introduction}

There has been increasing interest in the study of income inequality over recent years in the fields of both research and politics. Since the seminal contributions of Piketty (2001 and 2014), Piketty and Saez (2003) and Atkinson and Piketty (2007 and 2010) on the long-run evolution of income and wealth inequality in most industrialized countries, recent public debate has primarily focused on the role of income taxes in reducing inequality (Atkinson, 2014; Piketty, 2015). Personal income tax is the public policy instrument that is often considered when the main objective is to modify the post-tax income distribution (Poterba, 2007). However, the prospects of reducing income inequality through taxation crucially depend on how progressive a country's taxes are. Thus, the redistributive effect of income taxes has increasingly become a central issue in both developed and developing countries.

This paper casts new light on the redistributive effect of personal income tax in Ecuador between 2007 and 2011. Following common practice in the public policy evaluation literature, we first compute different indices of tax progressivity and redistributive effect, namely the Kakwani, Suits and ReynoldsSmolensky indices. Second, we employ microsimulation techniques to simulate the redistributive impact of Ecuador's personal income tax under different taxable income scenarios. We allow different definitions of income tax deductions and we present alternative scenarios that could potentially improve the redistributive effect of income taxes. Third, drawing on the top incomes literature (Piketty, 2001; Piketty and Saez, 2003; Atkinson and Piketty, 2010), we use homogenous series of top income shares in Ecuador from 2007 to 2011 (Cano, 2015) to compute the effective tax rates paid by top income groups. Finally, guided by the taxable income elasticity literature (Lindsey, 1987; Feldstein, 1999; Auten and Carroll, 1999; Gruber and Saez, 2002; Saez, 2001; Chetty, 2009; Saez, Slemrod and Giertz, 2012) and using different compensated and uncompensated elasticity values, we derive a range of optimal tax rates for the top $1 \%$ income group. Our results rely on individual income tax returns data compiled annually by the Ecuadorian Internal Revenue Service.

We have two main motivations for studying the redistributive effect of personal income tax in Ecuador. First, several recent studies have documented the decline of income inequality in most Latin American countries since the early 2000s (Gasparini and others, 2009; Cornia, 2010; López-Calva and Lustig, 2010; Lustig, López-Calva and Ortiz-Juárez, 2013; Cornia, 2014; ECLAC, 2012, 2013 and 2014), mainly owing to (i) a decline in the skill premium, (ii) a decrease in the urban-rural wage gap, (iii) public transfer programmes such as conditional cash transfer programmes and (iv) favourable external conditions. In addition, while taxation had a negligible effect on income inequality in previous decades (Cornia, Gómez Sabaini and Martorano, 2011), a growing body of literature has documented the positive effect of the tax reforms of the 2000s in reducing income inequality in the region (Jiménez, Gómez Sabaini and Podestá, 2010; Roca, 2009; Cetrángolo and Gómez Sabaini, 2006; Cornia, Gómez Sabaini and Martorano, 2011; Hanni, Martner and Podestá, 2015). The present paper aims to contribute to this growing literature by assessing the redistributive impact of personal income tax in Ecuador.

Alongside the emergence in the late 1990s of conditional cash transfer programmes, which promote long-term human capital accumulation among the less well-off (Rawlings and Rubio, 2005), policymakers in Latin America and the Caribbean have mainly focused on improving the way public transfer programmes are used to achieve fairer income distribution (e.g. through better targeting and coverage). The role of taxes in tackling income inequality has probably been treated as a secondary issue because Latin American tax systems have been based mainly on indirect taxes (value added tax and trade taxes), even though progressive income taxation began to be introduced in the region in the early twentieth century (Gómez Sabaini, 2006; Cornia, Gómez Sabaini and Martorano, 2011). In recent years, however, debate in Latin America has increasingly turned on the need to reinforce tax progressivity and to increase tax revenue and thereby improve public transfers. Indeed, social, economic and institutional reforms in most of Latin America and the Caribbean since the early 2000s have 
influenced a new wave of tax reform. ${ }^{1}$ Following Fairfield (2010) and Gómez Sabaini and Moran (2014), this may be characterized as a "second generation" of tax reforms aimed at: (i) improving tax revenues and the fairness of the tax system, (ii) increasing tax progressivity and (iii) strengthening the ability of tax agencies to fight evasion. Thus, progressive taxation and income redistribution have been the primary goals of Latin American tax policy over recent years, at least in theory (Cornia, Gómez Sabaini and Martorano, 2011).

Although significant progress has been made towards these objectives, ${ }^{2}$ challenges remain and further work is needed, since tax systems are still based on indirect taxes, making the entire system highly regressive. Goñi, López and Servén (2011) show, for instance, that income inequality after taxes and transfers has declined by less in Latin America and the Caribbean than in the countries of the Organization for Economic Cooperation and Development (OECD), whereas the Gini coefficient before fiscal policy is nearly the same in both groupings. The authors also show that the reduction in income inequality in Latin America and the Caribbean has mainly been achieved by public transfers, with taxes being of little help in tackling inequality. Ecuador's tax system is no exception. ${ }^{3}$ The 2008 tax reform was enacted precisely to increase the progressivity of personal income tax, promote tax equity and increase tax revenue. This involved, firstly, creating two additional income tax brackets and a top marginal tax rate of $35 \%$ and, secondly, introducing new personal income tax deductions for spending on housing, education, health, clothing and food. ${ }^{4}$ As yet, though, very little is known about the impact of this tax reform on income inequality in Ecuador.

A second motivation for this paper was the growing interest in the study of top income shares and the effective tax rates paid by high-income individuals. Following the seminal contributions of Piketty (2001 and 2014) and Piketty and Saez (2003) on the long-run distribution of top incomes in France and the United States, the relationship between income concentration and tax policy has received considerable attention in the fields of both research and politics. Following this literature, Cano (2015) constructed top annual income share series for Ecuador from 2004 to 2011 out of individual income tax return data, using population and income totals based on census estimates and national accounts, respectively, as external controls. In 2010, the share of total income accruing to the richest $1 \%$ of the population was between $14 \%$ and $17 \%$, depending on how the income used as the numerator of the share is defined. ${ }^{5}$ We employ these estimates in the present paper to calculate the effective tax rates paid by top income groups. A further motivation was the increasing interest in the question of how progressive income taxes ought to be. Using different estimates of elasticity and following the taxable income elasticity literature (Saez, 2001; Gruber and Saez, 2002), we derive a range of optimal tax rates for the top $1 \%$ income group.

The remainder of this paper is organized as follows. Section II describes data and methodology, section III presents results and section IV offers conclusions and discusses policy implications.

\footnotetext{
1 A detailed review of Latin American tax reforms and tax policy patterns is provided in Gómez Sabaini (2006), Cetrángolo and Gómez Sabaini (2006), Gonzalez and Martner (2009), Jiménez, Gómez Sabaini and Podestá (2010), Gómez Sabaini and Jiménez (2012), Tanzi (2013) and Gómez Sabaini and Moran (2013).

2 Technical reports prepared by the Economic Commission for Latin America and the Caribbean (ECLAC) have well documented the major achievements of the latest tax reforms in Latin America and the Caribbean, as has the latest report on revenue statistics in Latin America jointly produced by the Organization for Economic Cooperation and Development (OECD), the Inter-American Centre of Tax Administrations (CIAT), the Inter-American Development Bank (IDB) and ECLAC.

3 In Ecuador, revenue raised from indirect taxes such as value added tax (VAT) averaged 4.9\% of GDP over the period 1990-2000, increasing to nearly $8 \%$ of GDP in 2001-2013. In 2013, moreover, 53\% of total tax revenue came from indirect taxes and just under $21 \%$ from taxes on income, profits and capital gains (OECD/ECLAC/CIAT/IDB, 2015).

4 Personal tax deductions were introduced in the 2008 tax reform to promote tax equity. The main objective was precisely to allow low-income taxpayers to benefit from larger tax deductions.

5 In order to provide an accurate picture of incomes at the top of the distribution, Cano (2015) constructed top income share series for Ecuador using different criteria (e.g., net income, gross income) and different percentages of intermediate costs and deductions as the numerators of the shares. In 2011 , the income accruing to the top $1 \%$ was between $12 \%$ and $15 \%$.
} 


\section{Data and methods}

\section{Data}

Our estimates rely on individual income tax returns compiled yearly by the Ecuadorian tax administration. ${ }^{6}$ The tax returns database provides information on individuals that includes: (i) employee earnings in the form of wages and salaries, (ii) capital income (dividends, interest and other capital income), (iii) business income, (iv) self-employment income, (v) income from other sources and (vi) tax deductions, tax liabilities and taxes paid by tax filers.

The data used for the analysis come from three different tax forms: (i) form 102, used to report information on wages, self-employment income, business income, capital income and other possible sources of income from tax filers required to keep accounts (e.g. individuals engaging in commercial activities); (ii) form 102A, used to report information on wages, self-employment income, capital income and other possible sources of income from tax filers not required to keep accounts; (iii) form 107, used to report information on formal employees' wages and salaries. Personal income is taxed at progressive marginal tax rates ranging from $0 \%$ to $35 \%$. Individuals whose sole source of income is wages (i.e. employees) are not required to fill in a tax return because income tax is automatically withheld by employers. Nevertheless, employees earning income from sources other than wages (e.g. dividends, interest, rents) are required to consolidate all sources of income (e.g. wages and capital income) in a single annual tax return (tax form 102 or $102 \mathrm{~A}$ ). The same progressive rate schedule of between $0 \%$ and $35 \%$ is applied to total income. We identified the tax filers whose incomes were reported in both form 107 and form 102 or 102A, in order not to duplicate data on wages and salaries. In all such cases, we have only worked with the data from form 102 or 102A. Regarding capital income, before 2010 distributed dividends that had already been subject to corporation taxes were exempted from personal income tax to avoid double taxation. Since 2010, dividends received by individuals living in Ecuador have formed part of the personal income tax base. Income taxes in Ecuador are declared in United States dollars and are assessed at the individual level and not at the household level as they are, for instance, in the United States and in some European countries such as France, Germany and the United Kingdom.

By Latin American standards, the Ecuadorian income tax returns database is at roughly the midpoint in terms of the number of individuals covered. Almost $27 \%$ of the adult population (aged 20 and over) reported income to the Fiscal Administration in 2011, including those whose income was below the tax threshold. ${ }^{7}$ Comparison with other countries for which estimates of top income shares and tax incidence are available shows that this was lower than the adult population coverage in Chile (67\% in 2009) and Uruguay (74\% in 2012), but higher than that in Colombia (4\% in 2010) and Argentina (3\% in 2004). ${ }^{8}$

\footnotetext{
6 The Ecuadorian Internal Revenue Service (SRI) kindly agreed to give us access to the entire personal income tax returns database from 2004 to 2011. The database is composed of nearly 1.9 million observations on average (2.3 million in 2011). In this paper we work with the 2007-2011 period.

7 Data for the population aged 20 and over come from the Ecuadorian National Survey of Employment, Unemployment and Underemployment (ENEMDU) of December 2011.

8 The studies on top income shares and tax incidence are Fairfield and Jorratt (2016) for Chile, Burdín, Esponda and Vigorito (2014) for Uruguay, Alvaredo and Londoño (2013) for Colombia, and Alvaredo (2010) for Argentina. The low population coverage in Argentina and Colombia is probably due to the fact that their estimates exclude taxpayers whose sole source of income is wages.
} 


\section{Methods}

We rely on four complementary methods to assess the relationship between personal income tax and income inequality. First, to analyse the redistributive effect of income taxes, we compute different progressivity and redistribution indices commonly proposed by the impact evaluation literature: the Kakwani and Suits indices to measure the level of progressivity and the Reynolds-Smolensky index to measure the redistributive effect of Ecuador's personal income tax. At the same time, we draw the concentration curves for personal income tax deductions and tax liabilities, along with the pre-tax income Lorenz curve, for the years 2008 and 2010. These progressivity and redistribution indicators allow us to study the distributional effect of income taxes while comparing the pre-tax and post-tax income distributions.

The concentration curves and the Kakwani, Suits and Reynolds-Smolensky synthetic indices are derived from the classical approach of the Lorenz curve and the Gini coefficient. The Lorenz curve $\left(L_{p}\right)$ plots the cumulative percentage of income on the vertical axis against the cumulative percentage of individuals, ranked by income from poorest to richest, on the horizontal axis. The Gini coefficient $\left(G_{p}\right)$ compares the area between the Lorenz curve $\left(L_{p}\right)$ and the diagonal of perfect equality (45) against the total area under the diagonal, taking values of between 0 (absolute equality) and 1 (absolute inequality).

The Lorenz curve and Gini coefficient can be reformulated to assess changes in income distribution, notably when taxes are included. The concentration curve plots the cumulative percentage of tax liabilities on the vertical axis against the cumulative percentage of individuals, ranked by income, on the horizontal axis. If the tax concentration curve lies farther than the Lorenz curve from the diagonal of perfect equality, taxes are more unequally distributed than income and thus are progressive. The corresponding concentration coefficient $C_{t}$, also known as the quasi-Gini coefficient, is interpreted analogously to the Gini coefficient.

The Kakwani progressivity index is calculated by comparing the tax concentration curve and the pre-tax income Lorenz curve. The Kakwani index is defined as twice the area between the pre-tax income Lorenz curve and the tax concentration curve. Thus, it is equivalent to the difference between the concentration coefficient of taxes (or quasi-Gini coefficient) and the Gini coefficient of pre-tax income distribution (Kakwani, 1977):

$$
K=C_{t}-G_{y}
$$

where $C_{t}$ is the concentration coefficient of taxes (or quasi-Gini coefficient) and $G_{y}$ is the Gini coefficient of pre-tax income distribution. A positive Kakwani index indicates that taxes are progressive (i.e. tax liabilities increase with income), a negative Kakwani index that taxes are regressive (i.e. tax liabilities decrease with income) and a Kakwani index of zero that taxes are proportional to income.

Another popular index of progressivity is the one proposed by Suits (1977), which measures the departure from proportionality by comparing the pre-tax income Lorenz curve with the diagonal line of perfect equality. The Suits index is an adaptation of the Gini coefficient and is constructed by plotting the cumulative percentage of taxes on the vertical axis against the cumulative percentage of income on the horizontal axis. As suggested by Amarante and others (2011), the Suits index can be formulated as:

$$
S=2 \int_{0}^{1}\left(i-C_{f}(i)\right) d i
$$

If taxes are proportional, the concentration curve of taxes coincides with the diagonal line of perfect equality $\left(45^{\circ}\right)$, and the Suits index will take the value of 0 . If taxes are progressive, the concentration 
curve will be below the line of perfect equality, and the Suits index will be positive. And if taxes are regressive, the concentration curve will be above the line of perfect equality, and the Suits index will be negative. For instance, if only high-income individuals paid taxes, the Suits index would take a value of 1 . Conversely, if only the poorest individuals paid taxes, the Suits index would take a value of -1 . Although the Kakwani and Suits indices are quite similar in design, there are some differences between them. As pointed out by Amarante and others (2011), while the Kakwani index integrates with respect to the population, the Suits index integrates with respect to income.

To measure the redistributive effect of income taxes, we make use of the Reynolds-Smolensky index, which measures how taxes affect after-tax income distribution, capturing the difference between the pre-tax and post-tax income Ginis as follows:

$$
R S=G_{y}-G_{y-t}
$$

where $G_{y}$ is the Gini coefficient before taxes and $G_{y-t}$ is the Gini coefficient after taxes (Reynolds and Smolensky, 1977). A positive Reynolds-Smolensky index indicates that taxes are progressive, because the post-tax income distribution is more equal than the pre-tax income distribution. A high ReynoldsSmolensky index value suggests that taxes have great redistributive potential.

Second, we use static microsimulation techniques to simulate the redistributive impact of personal income tax in Ecuador on different definitions of taxable income. For each observation we arithmetically simulate pre-tax income under two different counterfactual scenarios: (i) a 50\% threshold for costs and deductions and (ii) elimination of all income tax deductions. ${ }^{9}$ Counterfactual scenarios show what would occur if changes in income tax deductions were implemented. We then apply tax rates and income tax schedules in both counterfactual scenarios and for each observation to calculate tax liabilities and post-tax income. Finally, we calculate tax progressivity and redistribution indices for the scenarios simulated.

Third, to cast further light on the factors influencing the redistributive capacity of income tax policy in Ecuador, we compute effective tax rates paid by top income groups, using the top income share series constructed by Cano (2015) to calculate the income tax rates actually paid by high-income individuals.

Fourth, we draw on the taxable income elasticity literature and employ different international values for compensated and uncompensated elasticity (e.g. 0.2 and 0.5), as proposed by Saez (2001), to derive a range of optimal tax rates for the top $1 \%$ income group.

A word of caution is needed here. Our analysis relies on individual income tax returns and therefore does not take account of workers operating in the informal sector or individuals whose income does not exceed the standard personal allowance (US\$ 9,210 in 2011), with the exception of formal sector workers who are present in the database even though they do not earn enough to pay taxes. Our data were also affected by tax evasion and avoidance issues. Because of the methodological differences, our results are likely to differ from other studies on the redistributive impact of personal income tax in Ecuador (Roca, 2009; Hanni, Martner and Podestá, 2015), based on data from household surveys.

\footnotetext{
9 There are two different types of income tax deductions in Ecuador: (i) all costs and deductions that are mandatory by law; and (ii) personal income tax deductions for spending on housing, education, health, clothing and food allowed under the tax reform of 2008.
} 


\section{Results}

\section{Measuring tax progressivity and the redistributive effect of personal income tax}

This subsection assesses the progressivity and redistributive capacity of personal income tax in Ecuador over the period 2007-2011 (i.e. before and after the 2008 tax reform). As mentioned in the section on methods above, we compute the Kakwani and Suits indices to analyse the progressivity of personal income tax and the Reynolds-Smolensky index to measure its redistributive capacity. ${ }^{10}$ Table 1 presents the results.

Table 1

Ecuador: personal income tax progressivity and redistribution indicators

\begin{tabular}{llllll}
\hline Indicator & 2007 & 2008 & 2009 & 2010 & 2011 \\
\hline Pre-tax Gini & 0.6006 & 0.6558 & 0.6441 & 0.6378 & 0.5938 \\
\hline Post-tax Gini & 0.5921 & 0.6483 & 0.6377 & 0.6307 & 0.5844 \\
\hline Average tax rate & 0.0249 & 0.0267 & 0.0218 & 0.0234 & 0.0291 \\
\hline Reynolds-Smolensky index & 0.0085 & 0.0075 & 0.0064 & 0.0071 & 0.0093 \\
\hline Kakwani progressivity index & 0.3388 & 0.2756 & 0.2915 & 0.3023 & 0.3145 \\
\hline Suits progressivity index & 0.5711 & 0.4503 & 0.4752 & 0.528 & 0.4623 \\
\hline
\end{tabular}

Source: Prepared by the author, on the basis of the individual income tax returns database of the Ecuadorian Internal Revenue Service (SRI).

The Kakwani progressivity index $K$ is calculated as the difference between the tax concentration coefficient ${ }^{11}$ and the Gini coefficient for pre-tax income. If $K>0$, income taxes are progressive, while if $K<0$ income taxes are regressive and do not contribute to a reduction in income inequality. Results from the Kakwani index $K$ for 2007 (before the tax reform) and 2008 onward (after the tax reform), displayed in table 1, suggest that personal income tax is progressive in Ecuador, as it is positive throughout the period studied: 0.34 in 2007, 0.28 in 2008, 0.29 in 2009, 0.30 in 2010 and 0.32 in 2011. This shows that the cumulative percentage of income taxes paid by wealthy taxpayers is higher than the cumulative percentage of income taxes paid by the poorest individuals.

The same pattern emerges from the Suits index, interpreted analogously to the Gini coefficient. For instance, a Suits index value of 1 corresponds to the hypothetical situation in which high-income individuals alone pay the totality of income taxes (extreme progressivity), while a Suits index value of -1 corresponds to the extreme situation in which only the poorest individuals pay the totality of income taxes (extreme regressivity). The results displayed in table 1 show that the Suits index is positive over the period 2007-2011 (0.57 in 2007, 0.48 in 2009 and 0.46 in 2011), indicating that personal income tax is progressive in Ecuador. In addition, we follow Roca (2009) and Hanni, Martner and Podestá (2015) in calculating the share of total income taxes paid by each income decile. Like these authors, we find

\footnotetext{
${ }^{10}$ Progressivity and redistribution indices are computed using the PROGRES module developed for Stata by Philippe Van Kerm and Andreas Peichl of the Luxembourg Institute of Socio-Economic Research (LISER) and the Centre for European Economic Research (Van Kerm and Peichl, 2007).

${ }^{11}$ It will be recalled that the tax concentration coefficient, also known as the quasi-Gini coefficient, is the coefficient corresponding to the tax concentration curve.
} 
that nearly $90 \%$ of Ecuador's personal income tax is paid by the richest decile. This result shows that personal income tax in the country is highly progressive. ${ }^{12}$

As pointed out by Roca (2009, pp. 53-55), measurement of the progressivity and redistributive capacity of income taxes in Latin American countries should be seen as a theoretical exercise because of the high levels of tax evasion and avoidance, and also because of personal tax allowances. ${ }^{13}$ Moreover, Latin American countries are unfortunately characterized by large disparities of income. Indeed, Hanni, Martner and Podestá (2015) show that the share of total income accruing to the richest decile in Latin American countries averaged 32\% in 2012. Most probably because of the high levels of income concentration, tax evasion and tax avoidance, personal income tax in Ecuador is actually less progressive than documented in this section. For this reason, and to cast new light on the progressivity of income taxes, we compute effective tax rates paid by top income groups in section III.3.

In sum, the results from the Kakwani and Suits indices and those for the personal income tax burden suggest that personal income tax is generally progressive in Ecuador. These findings are in line with trends found by Roca (2009) and Hanni, Martner and Podestá (2015), which are based on household surveys.

From a theoretical point of view, progressive income taxes "push" the pre-tax income Lorenz curve towards the diagonal, making the after-tax income distribution less unequal. The magnitude of this movement is captured by the Reynolds-Smolensky index, which measures the difference between the Gini coefficient for pre-tax income and the Gini coefficient for post-tax income. The results of the Reynolds-Smolensky index for Ecuador are also displayed in table 1. At first glance, it can be seen that the pre-tax Gini coefficient is higher that the post-tax Gini coefficient over the period studied, suggesting that personal income tax effectively reduces income inequality. However, this reduction is so small as to be almost unobservable, with no significant change in the Reynolds-Smolensky index in any year. The Gini index after income taxes declines from 0.655 to 0.648 in 2008 and from 0.637 to 0.630 in 2010. These results reveal that although Ecuador's personal income tax is progressive, as shown by the Kakwani and Suits indices, its redistributive capacity is very weak. Moreover, no significant changes are observable between 2007 and 2008, i.e. before and after the tax reform which was actually enacted to increase tax progressivity and therefore income redistribution.

To cast further light on the factors that erode the redistributive capacity of personal income tax, we study the new personal income tax deductions introduced by the 2008 tax reform over the period 2008-2010. ${ }^{14}$ Figures 1 and 2 plot the pre-tax income Lorenz curve for 2008 and 2010, respectively (dark red lines), along with concentration curves for each type of personal income tax deduction and for income tax liabilities. ${ }^{15}$

Several observations arise from figures 1 and 2. First, the tax concentration curve (plotted in green) lies below the pre-tax Lorenz curve in both figures, showing that tax liabilities are more unequally distributed than income. ${ }^{16}$ This result is in line with previous evidence from the Kakwani and Suits indices showing personal income tax to be progressive.

\footnotetext{
12 This result probably reflects the fact that most tax filers present in the tax returns database, especially workers, earn less than the threshold above which income tax is levied.

${ }^{13}$ Roca (2009) suggests that nearly $70 \%$ of "lowest-income" individuals in Ecuador do not earn enough to pay taxes, and therefore tax evasion mostly concerns high-income individuals.

14 Unfortunately, we did not have access to microdata on personal income tax deductions for 2011.

${ }^{15}$ Concentration curves plot the cumulative percentage of different personal income tax deductions and tax liabilities against the cumulative percentage of population ranked by total income $\left(C_{p}\right)$.

${ }^{16}$ In other words, the share of tax liabilities accruing to low-income taxpayers is smaller than the share of tax liabilities accruing to wealthy taxpayers.
} 
Figure 1

Ecuador: Lorenz and concentration curves for income tax deductions and tax liabilities, 2008

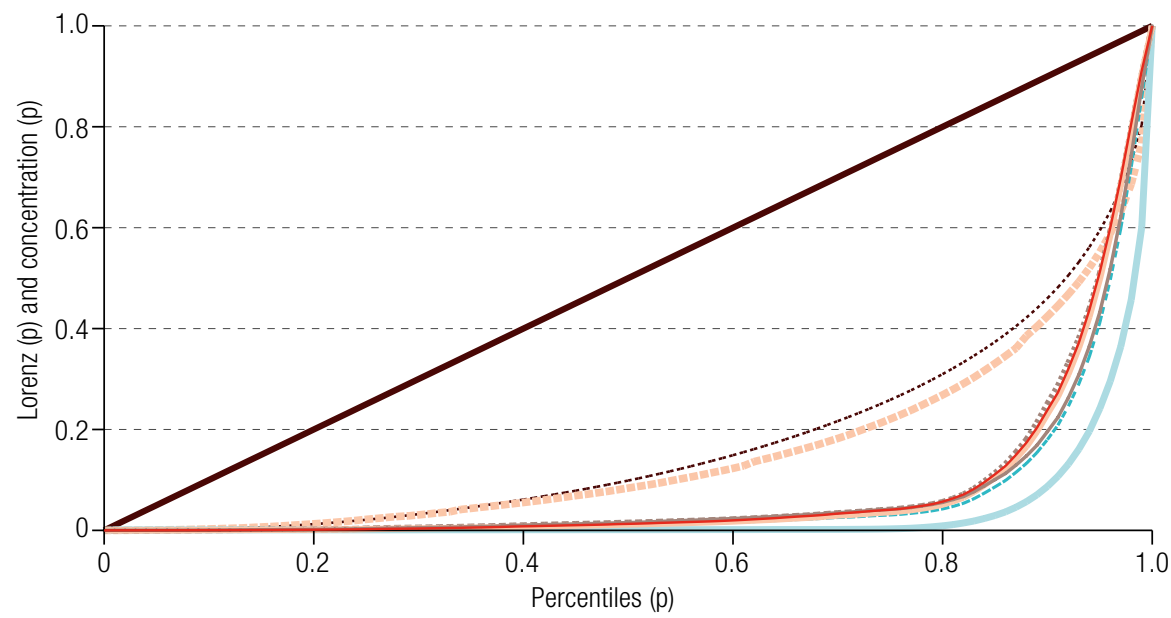

- $45^{\circ}$ line

-n I- Concentration (p): deduction for costs

— Concentration (p): tax deduction for clothing

-- - - Concentration (p): tax deduction for education

— Concentration (p): tax deduction for housing
...... Lorenz (p): 2008 income

Concentration (p): income tax

....... Concentration (p): tax deduction for food

- Concentration (p): tax deduction for health care

Source: Prepared by the author, on the basis of the individual income tax returns database of the Ecuadorian Internal Revenue Service (SRI).

Note: The chart plots the gross pre-tax income Lorenz curve alongside different concentration curves for income tax deductions and tax liabilities in 2008.

Figure 2

Ecuador: Lorenz and concentration curves for income tax deductions and tax liabilities, 2010

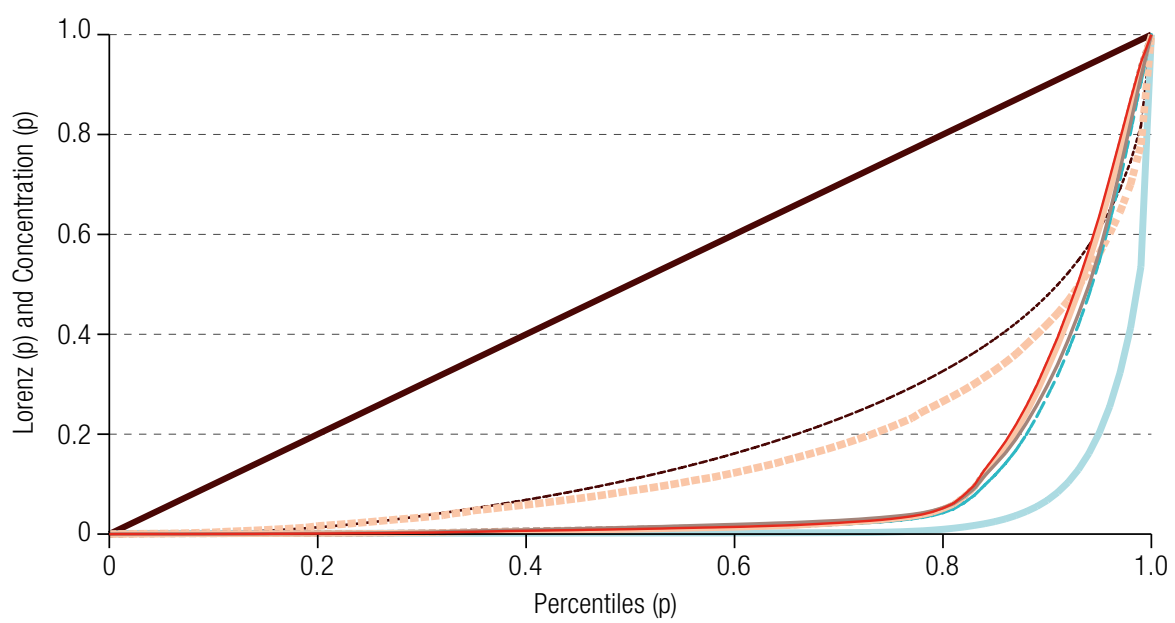

$45^{\circ}$ line

Concentration (p): income tax

...... Lorenz (p): 2010 income

— Concentration ( $\mathrm{p})$ : tax deduction for clothing

- $\sim$ Concentration (p): income tax

-- - - Concentration (p): tax deduction for education

. "... . Concentration (p): tax deduction for food

— Concentration (p): tax deduction for housing

Concentration (p): tax deduction for health care

Source: Prepared by the author, on the basis of the individual income tax returns database of the Ecuadorian Internal Revenue Service (SRI).

Note: The chart plots the gross pre-tax income Lorenz curve alongside different concentration curves for income tax deductions and tax liabilities in 2010 . 
Second, figures 1 and 2 both clearly show that the taxpayers who have benefited most from personal income tax deductions are those in the eightieth percentile and above. Similarly interpreting the tax liability concentration curves, we observe that the share of personal income tax deductions accruing to high-income taxpayers is greater than the share of personal income tax deductions accruing to the poorest taxpayers. Put differently, high-income individuals (from the eightieth percentile upward) are the beneficiaries of most of the new personal income tax deductions introduced by the 2008 tax reform. Cano (2015) shows that the top 5\% income share in Ecuador, controlled for the total income and total population variables, represented the top 22 centiles of the tax income distribution in 2008 and the top 19 centiles in 2011 (without the total population control variable). Thus, figures 1 and 2 show that the richest $5 \%$ have benefited the most from personal income tax deductions.

While all indicators suggest that the design of personal income tax in Ecuador is broadly progressive, a detailed analysis of income tax deductions shows that high-income individuals are more likely to reduce their taxable income through personal income tax deductions than middle- and low-income individuals, eroding the redistributive effect of progressive taxation. This result is in line with the results of the Reynolds-Smolensky index presented in table 1, leading us to confirm that the redistributive capacity of personal income tax is weak in Ecuador, as in most Latin American countries (Roca, 2009). Tax simulations carried out by ECLAC have also highlighted the fact that targeted public expenditure using revenue generated by stronger personal income tax is generally more redistributive than improvements associated with personal income tax itself.

\section{Microsimulation and income tax incidence: alternative scenarios}

To shed more light on the redistributive effect of personal income tax, this section employs microsimulation techniques at the level of the individual to capture how the pre-tax income distribution changes when legally mandated personal income tax deductions are reduced or eliminated. Following on from the preceding section, where we empirically demonstrated that the "winners" from personal income tax deductions were taxpayers belonging to the top $5 \%$ income group, ${ }^{17}$ since it is their taxable income that tax deductions reduce the most, the main objective of this subsection is to test whether the redistributive effect of personal income tax increases when tax deductions are modified.

Microsimulation models are often characterized as static, dynamic and behavioural. ${ }^{18}$ Static microsimulation models are traditionally employed to evaluate the immediate impact of policy modifications on individuals. In them, microunits of observation remain constant, and they take no account of ongoing changes in demographic composition or of behavioural changes due to policy shifts or the time dimension. By contrast, dynamic microsimulation models contain specific parameters that estimate individuals' responses to policy changes, and are generally employed to analyse long-term outcomes, intergenerational impacts, and socioeconomic and demographic projections under current policies, among other things (Bourguignon and Spadaro, 2006). Behavioural models, meanwhile, use microeconometric tools to estimate the effects of policy modifications on individuals' behaviour, usually in respect of the labour supply (Figari, Paulus and Sutherland, 2015).

We employ a static microsimulation model to analyse pre-tax and post-tax income distributions and tax liabilities under different simulated scenarios. Our main objective is to give a bird's eye view of possible redistributive effects if personal income tax deductions were modified. As our microsimulation

\footnotetext{
17 It will be recalled that income and population totals are used as external controls to construct top income share groups.

18 Spadaro (2007) and Figari, Paulus and Sutherland (2015) offer an excellent overview of microsimulation approaches and different microsimulation models typically employed to evaluate the impact of public policies.
} 
approach is static, we do not incorporate changes in individuals' behaviour resulting from tax modifications. Drawing on our micro level data, for each tax filer we arithmetically simulate pre-tax income for two different counterfactual scenarios. ${ }^{19}$ In the first scenario, we allow $50 \%$ of costs and deductions and remove personal income tax deductions. In the second, we remove income tax deductions of all kinds. We then employ statutory tax rates and tax tables for 2008, 2009 and 2010 to simulate the new tax liabilities and after-tax income for each individual under both scenarios.

The baseline and simulated scenarios are constructed as follows:

Baseline scenario 0: $Y_{0}-t_{0}$, where $Y_{0}$ is gross income and $t_{0}$ are tax liabilities reported by tax filers.

Scenario 1: $Y_{0}-t_{1}$, where $Y_{0}$ is gross income and $t_{1}$ are simulated tax liabilities when $50 \%$ of costs and deductions are allowed and all personal tax deductions are eliminated.

Scenario 2: $Y_{0}-t_{2}$, where $Y_{0}$ is gross income and $t_{2}$ are simulated tax liabilities when all tax deductions are eliminated.

The methodology described in subsection 1 is then used to compute inequality, progressivity and redistribution indicators for the simulated scenarios.

Table 2 presents the results of this tax policy evaluation over three years. In 2008, first, the Kakwani and Suits progressivity indices are positive in all the simulated scenarios, meaning that personal income tax remains progressive, as it is in the baseline. This result was to be expected, since no new marginal tax rates or new income tax brackets are created in either scenario 1 or scenario 2 , with the simulations in fact employing the same tax rates as scenario 0. However, the Reynolds-Smolensky index, which captures the difference in the Gini coefficient before and after personal income tax, changes more substantially in both simulated scenarios.

Table 2

Ecuador: static microsimulation of the distributional effects of personal income tax, 2008-2011

\begin{tabular}{|c|c|c|c|c|c|c|c|c|c|}
\hline \multirow{2}{*}{ Indicator } & \multicolumn{3}{|c|}{2008} & \multicolumn{3}{|c|}{2009} & \multicolumn{3}{|c|}{2010} \\
\hline & Baseline & Scenario 1 & Scenario 2 & Baseline & Scenario 1 & Scenario 2 & Baseline & Scenario 1 & Scenario 2 \\
\hline Pre-tax Gini & 0.6558 & 0.6123 & 0.6504 & 0.6441 & 0.5993 & 0.6396 & 0.6378 & 0.5911 & 0.6331 \\
\hline Post-tax Gini & 0.6483 & 0.581 & 0.6140 & 0.6377 & 0.5679 & 0.6027 & 0.6307 & 0.5607 & 0.5969 \\
\hline Average tax rate & 0.0267 & 0.0872 & 0.1106 & 0.0218 & 0.0847 & 0.1086 & 0.0234 & 0.0814 & 0.1060 \\
\hline $\begin{array}{l}\text { Reynolds- } \\
\text { Smolensky index }\end{array}$ & 0.0075 & 0.0313 & 0.0364 & 0.0064 & 0.0313 & 0.0369 & 0.0071 & 0.0303 & 0.0362 \\
\hline $\begin{array}{l}\text { Kakwani progressivity } \\
\text { index }\end{array}$ & 0.2756 & 0.3274 & 0.2922 & 0.2915 & 0.3385 & 0.3025 & 0.3023 & 0.3425 & 0.3058 \\
\hline Suits progressivity index & 0.4503 & 0.5797 & 0.5343 & 0.4752 & 0.5875 & 0.5421 & 0.528 & 0.5851 & 0.5409 \\
\hline
\end{tabular}

Source: Prepared by the author, on the basis of the individual income tax returns database of the Ecuadorian Internal Revenue Service (SRI).

Note: This table presents progressivity and redistribution indicators under different simulated scenarios. The baseline is the actual situation. In scenario 1, the personal income tax deductions mandated by the 2008 tax reform are eliminated and other legal tax deductions are allowed to the extent of $50 \%$. In scenario 2, both tax deductions and personal income tax deductions are eliminated.

Whereas the redistributive effect of personal income tax is very weak in scenario 0 (baseline), with the Gini coefficient declining from 0.656 before tax to 0.648 after tax, simulated scenario 1 , in which the new personal income tax deductions are eliminated, presents a larger redistributive effect.

Indeed, the Reynolds-Smolensky index rises from 0.0075 (baseline) to 0.0313 (scenario 1), with income inequality as measured by the Gini coefficient would decline by nearly 3 points, from 0.61

${ }^{19}$ A counterfactual scenario shows what would happen if a policy change were implemented. 
to 0.58 , after tax policy. Put differently, simulated results from scenarios 1 and 2 suggest that the redistributive effect of personal income tax would be greater if personal income tax deductions had not been introduced by the 2008 tax reform. The same pattern is found for 2009 and 2010. Table 2 shows that personal income tax remains progressive in all simulated scenarios. Moreover, when personal income tax deductions are eliminated (simulated scenario 1), the redistributive effect of direct taxation increases.

The results for scenario 2, where all tax deductions (personal tax deductions and other legal deductions) are eliminated, are quite similar to those already observed for scenario 1 in all years. The redistributive effect of personal income tax, as measured by the Reynolds-Smolensky index, increases by nearly 4 points, with the Gini coefficient declining from 0.65 before income tax to 0.61 after tax in 2008. Similar patterns are observed in 2009 and 2010.

To summarize, the results of the simulated scenarios confirm that the personal income tax system is progressive. Moreover, these scenarios show that the redistributive effect of income taxes could be greater if tax deductions in general were regulated. We have simulated extreme cases in which all tax deductions are eliminated, but we know that some kinds of deductions are needed to increase income tax fairness. In Ecuador, the introduction of personal tax deductions has created incentives for individuals, especially those belonging to the top 5\%, to reduce their taxable income and therefore tax liabilities. As suggested earlier, this cancels out the progressivity effect theoretically sought by the tax reform. It is therefore imperative to properly regulate tax allowances and tax deductions in the country.

To throw more light on other factors that erode the redistributive effect of personal income tax, the next section analyses the effective tax rate paid by high-income individuals over the period 2007-2011. We then draw on the literature dealing with the elasticity of taxable income to compute optimal tax rates for high-income groups, and propose policy recommendations.

\section{Effective tax rates paid by top income groups}

\section{(a) Constructing top income share series}

We start our analysis by constructing series of top income shares for the period 2007-2011. As in Cano (2015), we follow the standard top incomes literature (Piketty, 2001; Piketty and Saez, 2003; Atkinson and Piketty, 2007; Atkinson, Piketty and Saez, 2011), constructing first the top 1\% income series (denoted P99-100) and then series for a number of finer fractiles: P99.5-100 (the top 0.5\%), P99.9-100 (the top 0.1\%), and P99.99-100 (the top 0.01\%).

Each fractile is constructed relative to the total number of potential tax filers in the entire Ecuadorian population of adults aged 20 and over, which, as pointed out by Piketty (2003), should not be confused with the actual number of tax returns filed. Income is defined as being prior to personal income taxes. This definition includes all items reported on tax returns: salaries and wages, pensions, self-employment income, net income from unincorporated businesses, dividends, interest, other capital and rental income and other income items. We then compute income shares by dividing the income amounts accruing to each fractile (P99-100, P99.9-100, P99.99-100) by a control total for income. Atkinson, Piketty and Saez (2011) propose two different methods for computing this control. The first starts from income tax data and adds the income of non-filers, while the second computes an external control total derived from national accounts. In this paper, as in Cano (2015), we follow the second approach, also employed by Piketty (2001) and Piketty and Saez (2003), and construct a control total for income from national accounts as follows: balance of primary household income, plus social benefits other than social transfers in kind, minus employers' actual social contributions, minus employers' imputed social contributions, 
minus attributed property income of insurance policyholders, minus imputed rentals for owner-occupied housing, minus fixed capital consumption. This approach generates a control variable for total income of about $59 \%$ to $66 \%$ of gross domestic product (GDP), depending on the year. The results show the share of total income accruing to the richest 1\% income group in 2010 ranging from 14\% to 17\%, depending on the definition of income employed as the numerator of the share. ${ }^{20}$

Once top income share series have been constructed, we analyse the effective tax rates paid by these groups. ${ }^{21}$ This paper is a contribution to the growing literature analysing not only top income dynamics but also their tax policy implications (Piketty and Saez, 2003; Saez and Veall, 2005; Landais, Piketty and Saez, 2011; Alvaredo and Londoño, 2013; Burdín, Esponda and Vigorito, 2014; Fairfield and Jorratt, 2016).

Table 3 presents the results for effective tax rates paid by top income groups. While personal income in Ecuador is taxed at progressive marginal rates rising from $0 \%$ to $35 \%$, the effective tax rates paid by very high-income individuals are lower because of tax deductions, tax exemptions and probably tax evasion. Over the period 2007-2011, the top 1\% income group paid an average effective tax rate of about $7 \%$ and the top $0.1 \%$ an average effective tax rate of $9.4 \%$. Our results show that, other than in 2010, average effective tax rates decreased within top income groups, especially for the top $0.1 \%, 0.05 \%, 0.01 \%$ and $0.001 \%$ income groups. For instance, while the average effective tax rate of the top $1 \%$ income group was nearly $6.3 \%$ in 2009 , the average tax rate of the top $0.001 \%$ income group was $1.9 \%$.

This situation is connected with the composition of income in top groups and with the fact that capital income is taxed less than wage income. Cano (2015) analysed the composition of income in top groups and found that in 2011 the income of the top $1 \%$ was mainly composed of salaries (45\%) and income from business activities (27\%) or self-employment (21\%), and only to a lesser extent of capital income (7\%). Meanwhile, the income of the top $0.01 \%$ comprised a smaller share of salaries (16\%) but larger ones of income from business activities (29\%), self-employment income (28\%) and capital income (27\%). It is interesting to note how much the composition of income varied within the top decile (P90-100). While the share of salary income clearly decreased up the scale, that from self-employment and business activities increased up to the top $0.1 \%-0.01 \%$ before decreasing again towards the top $0.01 \%$. By contrast, the share of capital income increased at the very top. For instance, while the share of capital was $4 \%$ in the top $10 \%$ and just under $1.7 \%$ in the top 10\%-5\% in 2011, it was 50\% in the top $0.001 \%$. The rising share of capital income in very high-income groups suggests that those whose income comes from this source are the largest group at the top of the income distribution in Ecuador.

It should be noted that table 3 displays a marked difference between the situation in 2007 and that from 2008 onwards, as average tax rates for very high-income groups dropped from their 2007 level, although they recovered significantly in 2010. In our view, the fall-off between 2007 and 2009 is probably explained by high-income individuals reducing their taxable income through tax deductions, especially the new personal income deductions allowed by the 2008 tax law. In this subsection, we have shown graphically that the new personal income deductions were very much concentrated at the upper end of the distribution (i.e. from the eightieth percentile upward or the top 5\% when a control total for population is used). The results presented in this section suggest that the richest $0.1 \%$ have probably benefited most from this kind of tax deduction.

\footnotetext{
20 In order to provide an accurate picture of incomes at the top of the distribution, Cano (2015) constructed top income share series for Ecuador under different definitions of income as the numerator of the share.

${ }^{21}$ Effective tax rates are defined as individual income taxes paid divided by declared earned income.
} 
Table 3

Ecuador: average effective income tax rates in top income groups, 2007-2011

\begin{tabular}{|c|c|c|c|c|c|c|c|c|c|c|c|c|c|}
\hline Year & $\begin{array}{l}\text { Top } \\
10 \%\end{array}$ & $\begin{array}{l}\text { Top } \\
5 \%\end{array}$ & $\begin{array}{l}\text { Top } \\
1 \%\end{array}$ & $\begin{array}{c}\text { Top } \\
0.5 \%\end{array}$ & $\begin{array}{c}\text { Top } \\
0.1 \%\end{array}$ & $\begin{array}{c}\text { Top } \\
0.05 \%\end{array}$ & $\begin{array}{c}\text { Top } \\
0.01 \%\end{array}$ & $\begin{array}{c}\text { Top } \\
0.001 \%\end{array}$ & $\begin{array}{c}\text { Top } \\
1.0 \%- \\
0.5 \%\end{array}$ & $\begin{array}{c}\text { Top } \\
0.5 \%- \\
0.1 \%\end{array}$ & $\begin{array}{c}\text { Top } \\
0.1 \%- \\
0.05 \%\end{array}$ & $\begin{array}{c}\text { Top } \\
0.05 \%- \\
0.01 \%\end{array}$ & $\begin{array}{c}\text { Top } \\
0.01 \%- \\
0.001 \%\end{array}$ \\
\hline 2007 & 3.1 & 4.0 & 7.4 & 9.0 & 12.4 & 13.3 & 12.2 & 6.8 & 3.6 & 6.4 & 10.3 & 14.2 & 15.1 \\
\hline 2008 & 3.7 & 4.7 & 7.2 & 8.0 & 8.5 & 7.7 & 5.8 & 2.4 & 5.1 & 7.5 & 10.3 & 9.4 & 7.6 \\
\hline 2009 & 3.1 & 3.9 & 6.3 & 6.9 & 7.0 & 6.2 & 4.4 & 1.9 & 4.4 & 6.9 & 9.1 & 8.0 & 5.9 \\
\hline 2010 & 3.3 & 4.2 & 7.0 & 7.9 & 9.5 & 9.7 & 9.6 & 8.8 & 4.3 & 6.5 & 8.9 & 9.9 & 9.9 \\
\hline 2011 & 4.7 & 6.2 & 8.7 & 9.3 & 9.7 & 9.2 & 6.6 & 3.7 & 7.3 & 9.0 & 10.9 & 10.7 & 8.9 \\
\hline
\end{tabular}

Source: Prepared by the author, on the basis of the individual income tax returns database of the Ecuadorian Internal Revenue Service (SRI).

Note: This table displays average effective tax rates in top income groups, using the gross income criterion (business income is net of costs and deductions).

These results lead us to believe that despite the high level of income concentration, high-income individuals pay very low effective income tax rates. In addition, although all the synthetic indicators (which are more sensitive to changes in the middle of the distribution than at the tails) suggest that personal income tax in Ecuador is progressive, a more thorough analysis of tax rates actually paid by high-income individuals shows that tax rates decrease within top income groups.

\section{Using elasticities to derive optimal tax rates for high-income individuals}

This subsection draws on the taxable income elasticity literature to derive optimal income tax rates for top income groups. We employ different compensated and uncompensated elasticity values as proposed by Saez (2001) and derive a range of optimal tax rates for the top 1\% income group. Unfortunately, we were not able to calculate the elasticity of taxable income with respect to marginal rates using the 2008 tax reform as a natural experiment, because the results were heavily influenced by changes in population coverage between 2007 and 2008, with the percentage of adults included in the tax returns database increasing from 18\% in 2007 to nearly 27\% in 2011 (see chart in annex A1). Since the changes in population coverage distorted our elasticity results, we decided to employ standard elasticity values proposed by the literature. Fairfield (2010) proceeded in the same way to estimate optimal tax rates for high-income individuals in Chile and Argentina. ${ }^{22}$

We proceed as follows. First, following the top incomes literature (Atkinson, Piketty and Saez, 2011), we calculate the inverted Pareto coefficient $(\beta)$ for the period 2007-2011 as follows:

$$
\begin{gathered}
\alpha=\frac{1}{1-\left[\log \frac{S_{1}}{S_{0.1}} / \log 10\right]} \\
\beta=\frac{\alpha}{\alpha-1}
\end{gathered}
$$

where $S_{1}$ is the top $1 \%$ income share and the top $0.1 \%$ income share. As pointed out by Atkinson, Piketty and Saez (2011), a higher inverted Pareto coefficient $\beta$ yields a flatter upper tail in the distribution. Borrowing the explanation proposed by these authors, if $\beta=2$ then the average income of individuals

\footnotetext{
22 We computed the elasticity of taxable income with respect to marginal tax rates for high-income individuals by following Riihela, $\left(\log S_{1}-\log S_{0}\right)$

Sullstrom and Tuomala (2014), thus: $\epsilon=\frac{\left(\log S_{1}-\log S_{0}\right)}{\log \left(1-t_{1}\right)-\log \left(1-t_{0}\right)}$, where $S_{1}$ is the top $1 \%$ income share after a tax reform, $S_{0}$ the top $1 \%$ before the reform, $t_{1}$ the top marginal tax rate after reform and $t_{0}$ the marginal tax rate before reform. Unfortunately, our results were heavily influenced by the increase in adult population coverage between 2007 and 2008.
} 
with incomes above US $\$ 100,000$ is US $\$ 200,000$ and the average income of individuals with incomes above US\$ 1 million is US\$ 2 million. Once our $\beta$ Pareto parameters have been constructed, we follow Saez (2001) and derive optimal tax rates by applying his formula as follows:

$$
\tau=\frac{1-g}{1-g+\zeta^{u}+\zeta^{c}(a-1)}
$$

where $\tau$ is the optimal tax rate, $g$ the redistributive goal of government, ${ }^{23} \alpha-1$ the Pareto parameter, $\xi^{u}$ the uncompensated elasticity and $\xi^{c}$ the compensated elasticity. As suggested by Saez, the case $g=0$ corresponds to one where the government does not value the marginal consumption of high-income individuals and sets the highest top rate it can to maximize its tax revenue from them. The formula proposed by Saez is mostly specialized for $g=0$. Moreover, as suggested by Saez, our estimates of optimal tax rates are adjusted for the presence of a value added tax (VAT) of $12 \%$ as follows: $(1-t)^{\star}$, where $\tau$ is the consumption tax rate.

Since there is little agreement in the taxable income elasticity literature when it comes to fixed values for the elasticity of top income individuals' taxable income, we follow Saez (2001) and Fairfield (2010) in deriving optimal tax rates by testing different elasticity values as follows: uncompensated elasticities of $0,0.2$ and 0.5 and compensated elasticities of $0.2,0.5$ and 0.8 . Additionally, we present both results when $g=0$ and $g=0.25$.

Table 4

Ecuador: elasticity-derived optimal tax rates for high-income individuals, 2007-2011

\begin{tabular}{|c|c|c|c|c|c|c|c|c|c|}
\hline \multirow{2}{*}{$\begin{array}{l}\text { Uncompensated elasticity } \\
\text { Compensated elasticity }\end{array}$} & & \multicolumn{3}{|c|}{0} & \multicolumn{3}{|c|}{0.2} & \multicolumn{2}{|c|}{0.5} \\
\hline & & 0.2 & 0.5 & 0.8 & 0.2 & 0.5 & 0.8 & 0.5 & 0.8 \\
\hline \multicolumn{10}{|l|}{$g=0$} \\
\hline Year & $\beta$ & & & & & & & & \\
\hline 2007 & 1.979 & $74 \%$ & $59 \%$ & $49 \%$ & $63 \%$ & $52 \%$ & $44 \%$ & $44 \%$ & $39 \%$ \\
\hline 2008 & 2.023 & $73 \%$ & $58 \%$ & $48 \%$ & $63 \%$ & $51 \%$ & $44 \%$ & $44 \%$ & $38 \%$ \\
\hline 2009 & 2.078 & $72 \%$ & $57 \%$ & $47 \%$ & $62 \%$ & $51 \%$ & $43 \%$ & $43 \%$ & $37 \%$ \\
\hline 2010 & 1.961 & $74 \%$ & $59 \%$ & $50 \%$ & $63 \%$ & $52 \%$ & $45 \%$ & $44 \%$ & $39 \%$ \\
\hline 2011 & 1.953 & $74 \%$ & $60 \%$ & $50 \%$ & $63 \%$ & $52 \%$ & $45 \%$ & $45 \%$ & $39 \%$ \\
\hline \multicolumn{10}{|l|}{$g=0.25$} \\
\hline Year & $\beta$ & & & & & & & & \\
\hline 2007 & 1.979 & $70 \%$ & $53 \%$ & $43 \%$ & $58 \%$ & $46 \%$ & $38 \%$ & $38 \%$ & $32 \%$ \\
\hline 2008 & 2.023 & $69 \%$ & $52 \%$ & $42 \%$ & $57 \%$ & $45 \%$ & $37 \%$ & $37 \%$ & $32 \%$ \\
\hline 2009 & 2.078 & $68 \%$ & $51 \%$ & $41 \%$ & $57 \%$ & $44 \%$ & $36 \%$ & $37 \%$ & $31 \%$ \\
\hline 2010 & 1.961 & $70 \%$ & $54 \%$ & $43 \%$ & $58 \%$ & $46 \%$ & $38 \%$ & $38 \%$ & $33 \%$ \\
\hline 2011 & 1.953 & $70 \%$ & $54 \%$ & $44 \%$ & $58 \%$ & $46 \%$ & $39 \%$ & $38 \%$ & $33 \%$ \\
\hline
\end{tabular}

Source: Prepared by the author, on the basis of the individual income tax returns database of the Ecuadorian Internal Revenue Service (SRI).

Note: Following Saez (2001), this table displays optimal tax rates for high-income individuals, with $g$ being the ratio of social marginal utility with infinite income over the marginal value of public funds, $\beta$ the Pareto parameter, $\xi^{U}$ the uncompensated elasticity and $\xi^{C}$ the compensated elasticity. The results are based on income tax returns data. The $\beta$ Pareto parameter was computed using top income share series. Optimal tax rates are adjusted for the presence of VAT at 12\%.

Table 4 displays the optimal top marginal tax rates computed for Ecuador. Assuming that elasticities are the same as in the United States at nearly 0.2 (both compensated and uncompensated), the optimal top marginal tax rate for high-income individuals is between $57 \%$ and $63 \%$. The proposed top marginal tax rates are naturally higher than the current top marginal tax rate of $35 \%$. Our results

\footnotetext{
${ }^{23}$ The concept of a social welfare function in the computation of top marginal tax rates is very well documented by Saez (2001) and Diamond and Saez (2011).
} 
are in line with Fairfield's for Chile and Argentina, as that author proposes optimal tax rates of between $55 \%$ and $64 \%$ for Chile and between 56\% and 59\% for Argentina, assuming elasticities similar to those for the United States. For France, Saez (2001) used taxable income elasticities to propose an optimal tax rate for high-income individuals of $75 \%$.

\section{Conclusions}

In this paper, we have studied the relationship between tax policy and income inequality in Ecuador, obtaining several empirical results. First, personal income tax in Ecuador is broadly progressive, with the Kakwani and Suits progressivity indices and concentration curve analysis showing that the richest individuals generally pay more income tax than the poorest ones. When we analysed the effective tax rates paid by very high-income individuals, however, we found that these decreased within top income groups, especially within the top $0.1 \%, 0.05 \%, 0.01 \%$ and $0.001 \%$.

Second, the redistributive capacity of personal income tax is very weak. The Reynolds-Smolensky redistribution index suggests that income inequality is only one point lower after income tax than before it, declining from 0.66 to 0.65 in 2008 and from 0.64 to 0.63 in 2010. That redistributive capacity is so slight is mainly due to personal income tax deductions, which are mostly employed by high-income individuals.

Third, results obtained from the concentration curve approach showed that the tax filers benefiting most from personal income tax deductions during the period 2008-2010 were those from the eightieth percentile of the tax database upward (corresponding to the top 5\% when a control variable for total population is employed). High-income individuals are more likely to reduce their taxable income through legal income deductions, thereby eroding the tax base and cancelling out the distributive effect sought by the 2008 tax reform. The results of our static microsimulation exercise showed that the redistributive effect of personal income tax could be greater if tax deductions were better targeted and controlled.

Fourth, despite the reversal of the trend in 2010, average effective tax rates paid by high-income individuals are very low when dividends are an integral part of the personal income tax base, with the top $1 \%$ income group paying an average effective tax rate of $7 \%$ and the top $0.1 \%$ a rate of $9.4 \%$ over the entire period.

Fifth, we have used the taxable income elasticity literature to derive optimal tax rates for highincome individuals. While the current top marginal tax rate in Ecuador is 35\%, our results suggest that the optimal top rate could be between $57 \%$ and $63 \%$.

Finally, it is important to stress the vital need to close tax loopholes, notwithstanding the efforts made by the Ecuadorian Internal Revenue Service in recent years.

The new personal income tax deductions, which were introduced to improve tax equity, are too much of a blunt instrument, and policymakers should consider other ways of modifying the tax burden of low- and middle-income taxpayers. Policymakers should also consider improving the targeting of income tax deductions at the top of the income distribution.

Moreover, our findings suggest that it would be possible to create a more progressive rate structure for personal income tax in Ecuador, along with a higher top marginal tax rate. Naturally, there is the concern that increasing top marginal tax rates could affect work rates and business creation and therefore economic growth. Nevertheless, empirical research (Piketty, Saez and Stantcheva, 2014) has proved that certain countries such as the United States and the United Kingdom, where top marginal tax rates have been greatly reduced across time, have not grown faster than countries which have maintained high tax rates. Top income inequality has increased, however. Thus, greater tax progressivity in Ecuador would lead to an increase in tax revenue and public investment, notably in education, skills and health care. 


\section{Bibliography}

Alvaredo, F. (2010), "The rich in Argentina over the Twentieth Century, 1932-2004", Top Incomes: a Global Perspective, A. B. Atkinson and T. Piketty, Oxford, Oxford University Press.

Alvaredo, F. and J. Londoño (2013), "High incomes and personal taxation in a developing economy: Colombia 1993-2010", CEQ Working Paper Series, No. 12, Commitment to Equity.

Amarante, $\mathrm{V}$. and others (2011), "Distributive impacts of alternative tax structures. The case of Uruguay", Working Paper, No. 09/11, Montevideo, University of the Republic.

Atkinson, A. B. (2014), "After Piketty?", The British Journal of Sociology, vol. 65, No. 4, Wiley.

Atkinson, A. B. and T. Piketty (2010), Top Incomes: a Global Perspective, Oxford, Oxford University Press. (2007), Top Incomes over the Twentieth Century. A Contrast between Continental European and Englishspeaking Countries, Oxford, Oxford University Press.

Atkinson, A. B., T. Piketty and E. Saez (2011), "Top incomes in the long run of history", Journal of Economic Literature, vol. 49, No. 1, Nashville, Tennessee, American Economic Association.

Auten, G. and R. Carroll (1999), "The effect of income taxes on household income", Review of Economics and Statistics, vol. 81, No. 4, Cambridge, Massachusetts, The MIT Press.

Bourguignon, F. and A. Spadaro (2006), "Microsimulation as a tool for evaluating redistribution policies", Journal of Economic Inequality, vol. 4, No. 1, Springer.

Burdín, G., F. Esponda and A. Vigorito (2014), "Inequality and top incomes in Uruguay: a comparison between household surveys and income tax micro-data", CEQ Working Paper Series, No. 1, Commitment to Equity.

Cano, L. (2015), "Income Inequality, Top Income Shares and Economic Mobility: Ecuador 2004-2011", thesis, Toulouse, University of Toulouse 1 Capitole.

Cetrángolo, O. and J. Gómez Sabaini (2006), Tributación en América Latina: en busca de una nueva agenda de reformas, ECLAC Books, No. 93 (LC/G.2324-P), Santiago, Economic Commission for Latin America and the Caribbean (ECLAC).

Chetty, R. (2009), "Is the taxable income elasticity sufficient to calculate deadweight loss? The implications of evasion and avoidance", American Economic Journal: Economic Policy, vol. 1, No. 2, Nashville, Tennessee, American Economic Association.

Cornia, A. (ed.) (2014), Falling Inequality in Latin America. Policy Change and Lessons, Oxford University Press. (2010), "Income distribution under Latin America's new left regimes", Journal of Human Development and Capabilities, vol. 11, No. 1, Taylor and Francis.

Cornia, A., J. Gómez Sabaini and B. Martorano (2011), "A new fiscal pact, tax policy changes and income inequality: Latin America during the last decade", UNU-WIDER Working Paper, No. 70, Helsinki, World Institute for Development Economics Research (UNU-WIDER).

Diamond, P. and E. Saez (2011), "The case for a progressive tax: from basic research to policy recommendations", Journal of Economic Perspectives, vol. 25, No. 4, Nashville, Tennessee, American Economic Association.

ECLAC (Economic Commission for Latin America and the Caribbean) (2014), Social Panorama of Latin America 2014 (LC/G.2635-P), Santiago.

(2013), Social Panorama of Latin America 2013 (LC/G.2580), Santiago. (2012), Social Panorama of Latin America 2012 (LC/G.2557-P), Santiago.

Fairfield, T. (2010), The Politics of Revenue-Raising Tax Reform in Latin America, Berkeley, University of California.

Fairfield, T. and M. Jorratt (2016), "Top income shares, business profits, and effective tax rates in contemporary Chile", Review of Income and Wealth, vol. 62, No. S1, Wiley.

Feldstein, M. (1999), "Tax avoidance and the deadweight loss of the income tax", Review of Economics and Statistics, vol. 81, No. 4, Cambridge, Massachusetts, The MIT Press.

Figari, F., A. Paulus and H. Sutherland (2015), "Microsimulation and policy analysis", Handbook of Income Distribution, vol. 2, A. B. Atkinson and F. Bourguignon, Amsterdam, Elsevier.

Gasparini, L. and others (2009), "A turning point? Recent developments on inequality in Latin America and the Caribbean", CEDLAS Working Papers, No. 081, Universidad Nacional de la Plata.

Gómez Sabaini, J. (2006), "Cohesión social, equidad y tributación. Análisis y perspectivas para América Latina", Políticas Sociales series, No. 127 (LC/L.2641-P), Santiago, Economic Commission for Latin America and the Caribbean (ECLAC).

Gómez Sabaini, J. and J. Jiménez (2012), "Tax structure and tax evasion in Latin America", Macroeconomía del Desarrollo series, No. 118 (LC/L.3455), Santiago, Economic Commission for Latin America and the Caribbean (ECLAC). 
Gómez Sabaini, J. and D. Moran (2013), "Política tributaria en América Latina: agenda para una segunda generación de reformas", Macroeconomía del Desarrollo series, No. 133 (LC/L.3632), Santiago, Economic Commission for Latin America and the Caribbean (ECLAC).

González, I. and R. Martner (2009), "Del síndrome del casillero vacío al desarrollo inclusivo: buscando los determinantes de la distribución del ingreso en América Latina", Working Paper, Santiago, Economic Commission for Latin America and the Caribbean (ECLAC).

Goñi, E., H. López and L. Servén (2011), "Fiscal redistribution and income inequality in Latin America", World Development, vol. 39, No. 9, Amsterdam, Elsevier.

Gruber, J. and E. Saez (2002), "The elasticity of taxable income: evidence and implications", Journal of Public Economics, vol. 84, No. 2, Amsterdam, Elsevier.

Hanni, M., R. Martner and A. Podestá (2015), "The redistributive potential of taxation in Latin America", CEPAL Review, No. 116 (LC/G.2643-P), Santiago, Economic Commission for Latin America and the Caribbean (ECLAC).

Jiménez, J. P., J. C. Gómez Sabaini and A. Podestá (2010), "Tax gap and equity in Latin America and the Caribbean", Fiscal Studies, No. 16, Santiago, Economic Commission for Latin America and the Caribbean (ECLAC).

Kakwani, N. (1977), "Measurement of tax progressivity: an international comparison", The Economic Journal, vol. 87, No. 345, Royal Economic Society.

Landais, C., T. Piketty and E. Saez (2011), Pour une révolution fiscale: un impôt sur le revenu pour le XXlème siècle, Paris, Seuil.

Lindsey, L. (1987), "Individual taxpayer response to tax cuts: 1982-1984, with implications for the revenue maximizing tax rate", Journal of Public Economics, vol. 33, No. 2, Amsterdam, Elsevier.

López-Calva, L. and N. Lustig (2010), Declining Inequality in Latin America: A Decade of Progress, Washington, D.C., Brookings Institution Press.

Lustig, N., L. López-Calva and E. Ortiz-Juárez (2013), "Deconstructing the decline in inequality in Latin America", Policy Research Working Paper, No. 6552, Washington, D.C., World Bank.

OECD/ECLAC/CIAT/IDB (Organization for Economic Cooperation and Development/Economic Commission for Latin America and the Caribbean/Inter-American Centre for Labour Administration/Inter-American Development Bank) (2015), Revenue Statistics in Latin America and the Caribbean, 1990-2013, Paris, OECD Publishing.

Piketty, T. (2015), "Putting distribution back at the center of economics: reflections on capital in the TwentyFirst Century", The Journal of Economic Perspectives, vol. 29, No. 1, Nashville, Tennessee, American Economic Association.

Piketty, T. (2014), Capital in the Twenty-First Century, Harvard University Press. (2003), "Income inequality in France, 1901-1998", Journal of Political Economy, vol. 111, No. 5, Chicago, The University of Chicago Press.

(2001), Les hauts revenus en France au XXe siècle: inégalités et redistributions, 1901-1998. Paris, Bernard Grasset.

Piketty, T. and E. Saez (2003), "Income inequality in the United States, 1993-1998", Quarterly Journal of Economics, vol. 118, No. 1, Oxford University Press.

Piketty, T., E. Saez e I. Stantcheva (2014), "Optimal taxation of top labor incomes: a tale of three elasticities", American Economic Journal, vol. 6, No. 1, Nashville, Tennessee, American Economic Association.

Poterba, J. (2007), "Income inequality and income taxation", Journal of Policy Modeling, vol. 29, No. 4, Amsterdam, Elsevier.

Rawlings, L. and G. Rubio (2005), "Evaluating the impact of conditional cash transfer programs", The World Bank Economic Review, vol. 20, No. 1, Oxford, Oxford University Press.

Reynolds, M. and E. Smolensky (1977), Public Expenditures, Taxes and the Distribution of Income: the United States 1950-1961, New York, Academic Press.

Riihela, M., R. Sullstrom and M. Tuomala (2014), "Top incomes and top tax rates: implications for optimal taxation of top incomes in Finland", Tampere Economic Working Papers Net Series, No. 88, University of Tampere.

Roca, J. (2009), "Tributación directa en Ecuador: evasión, equidad y desafíos de diseño", Macroeconomía del Desarrollo series, No. 85 (LC/L.3057-P), Santiago, Economic Commission for Latin America and the Caribbean (ECLAC).

Saez, E. (2001), "Using elasticities to derive optimal income tax rates", The Review of Economic Studies, vol. 68, No. 1, Oxford, Oxford University Press. 
Saez, E., J. Slemrod and S. Giertz (2012), "The elasticity of taxable income with respect to marginal tax rates: a critical review", Journal of Economic Literature, vol. 50, No. 1, Nashville, Tennessee, American Economic Association.

Saez, E. and M.R. Veall (2005), "The evolution of high incomes in Northern America: lessons from Canadian evidence", The American Economic Review, vol. 95, No. 3, Nashville, Tennessee, American Economic Association.

Spadaro, A. (2007), Microsimulation as a Tool for the Evaluation of Public Policies. Methods and Applications, BBVA Foundation.

Suits, D. (1977), "Measurement of tax progressivity", American Economic Review, vol. 67, No. 4, Nashville, Tennessee, American Economic Association.

Tanzi, V. (2013), Tax Reform in Latin America: a Long Term Assessment", Washington, D.C., Woodrow Wilson International for Scholars.

Van Kerm, P. and A. Peichl (2007), "Progress: Stata module to measure distributive effects of an income tax", Statistical Software Components, No. S456867, Boston College. 


\section{Annex A1}

Figure A1.1

Ecuador: tax filers as a proportion of total tax units (adults aged 20 and over), 2004-2011 (Percentages)

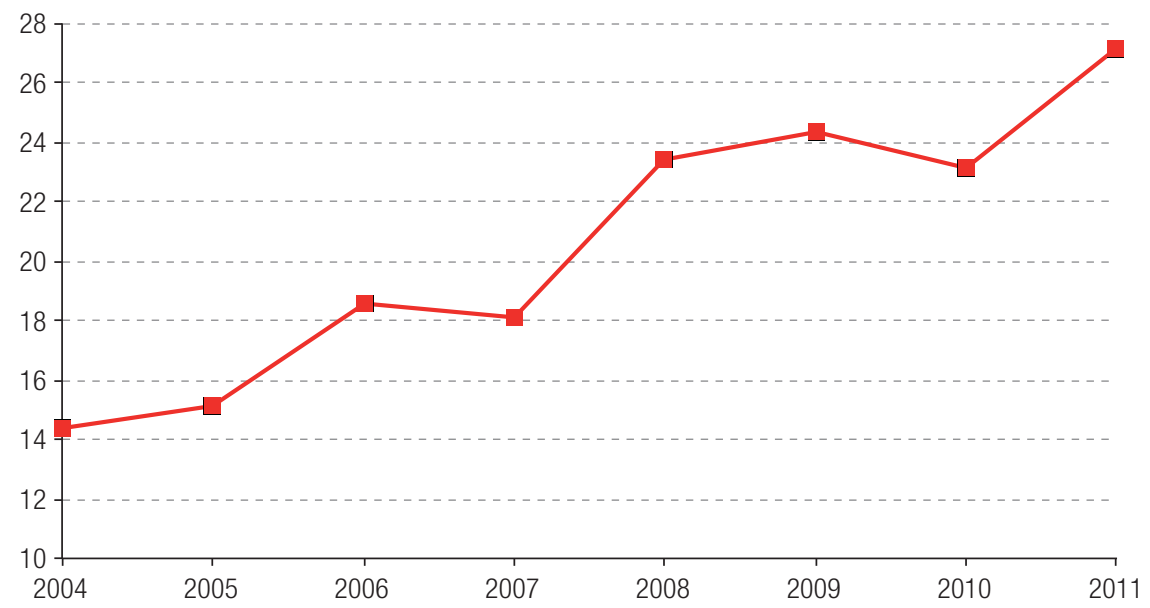

Source: Prepared by the author, on the basis of the individual income tax returns database of the Ecuadorian Internal Revenue Service (SRI) and population estimates provided by the National Institute of Statistics and Censuses (INEC). 